\title{
Effect of paclobutrazol and salicylic acid on antioxidants enzyme activity in drought stress in wheat
}

\author{
Efecto del paclobutrazol y ácido salicílico en la actividad \\ de enzimas antioxidantes bajo estrés hídrico en trigo \\ Amin Abbasi $^{1 *}$, Fariborz Shekari $^{2}$, Seyed Hamid Mustafavi ${ }^{1}$
}

\begin{abstract}
In this study wheat plants were treated with paclobutrazol (PBZ) and salicylic acid (SA) to analyze the enzyme activity and chlorophyll content under two drought stresses ( -6 and -12 bar). The Bahar cultivar was grown in a hydroponic system and drought stress was applied using PEG-6000 (-6 and -12 bar potential). Plants were kept under stress conditions for 10 days. Treatments with $5 \mathrm{mg} \mathrm{L}^{-1}$ paclobutrazol and $0.1 \mathrm{~mm}$ salicylic acid were carried out simultaneously with drought stress. The effects of PBZ and SA treatments on wheat were monitored by measuring the changes in CAT, APX, SOD, GPX, MDA, $\mathrm{H}_{2} \mathrm{O}_{2}$ and chlorophyll under drought stress. Both PBZ and SA increased antioxidant enzyme activity and showed significant differences ( $\mathrm{p}<0.001$ and 0.05). APX, SOD and CAT activity decreased under the drought condition but PBZ treatment resulted in increased APX activity in the drought stress treatment. However, seedlings supplemented under drought stress showed a profound increase in GPX activity (100\% and 53\% higher at -6 and -12 bar PEG on 3D) compared to stressed seedlings without SA spray. The results showed that paclobutrazol minimizes the negative effects of drought stress with evidence of enhancing chlorophyll content and antioxidant enzymes such as APX, CAT and GPX that reduces $\mathrm{H}_{2} \mathrm{O}_{2}$ and lipid peroxidation (MDA) content..
\end{abstract}

Key words: paclobutrazol, salicylic acid, antioxidant enzyme, drought stress, wheat.

\section{RESUMEN}

En este estudio, las plantas de trigo fueron tratadas con paclobutrazol (PBZ) y ácido salicílico (SA) para analizar la actividad enzimática y el contenido de clorofila en dos tensiones de humedad (-6 y -12 bar). El trigo variedad Bahar se cultivó en un sistema hidropónico y se sometió a estrés hídrico mediante el uso de PEG-6000 (-6 y -12 bar potencial). Las plantas se mantuvieron bajo condiciones de estrés durante 10 días. Los tratamientos fueron la aplicación de $5 \mathrm{mg} \mathrm{L}^{-1}$ de paclobutrazol y $0,1 \mathrm{~mm}$ de ácido salicílico y se aplicaron simultáneamente con el estrés hídrico. Los efectos de los tratamientos de PBZ y SA en trigo fueron monitoreados por medio de la medición de los cambios en el CAT, APX, SOD, GPX, MDA, $\mathrm{H}_{2} \mathrm{O}_{2}$ y clorofila en condiciones de sequía. En ambos tratamientos aumentó la actividad de la enzima antioxidante con diferencias significativas ( $\mathrm{p}<0,001$ y 0,05 ). La actividad de APX, SOD y CAT disminuyó bajo condiciones de sequía, pero el tratamiento PBZ aumentó la actividad de APX en el tratamiento de estrés por sequía. Las plantas del semillero bajo estrés hídrico aumentaron significativamente la actividad de GPX (100 y 53\% más altos en -6 y -12bar PEG en 3D) respecto de las plantas del semillero estresadas sin SA. Los resultados sugieren que la aplicación de paclobutrazol minimiza los efectos negativos del estrés hídrico aumentando la concentración de clorofila y enzimas antioxidantes como APX, CAT y GPX que reduce el contenido de $\mathrm{H}_{2} \mathrm{O}_{2}$ y peróxidos de lípidos (MDA).

Palabras clave: paclobutrazol, ácido salicílico, antioxidante, enzimas, estrés hídrico, trigo.

Abbreviations: ${ }^{1} \mathrm{O}_{2}$ singlet oxygen; ABA-abscisic acid; AOX-alternative oxidase; APX-ascorbate peroxidase; CAT-catalase; Chlchlorophyll; $\mathrm{CO}_{2}$-carbon dioxide; DMSO-dimethyl sulfoxide; EDTA- ethylenediaminetetraacetic acid; GPX glutathione peroxidase; $\mathrm{H}_{2} \mathrm{O}_{2}$-hydrogen peroxide; LOOHs-lipid hydroperoxides; MDAmalondialdehyde; NADPH-nicotinamide adenosine dinucleotide phosphate; NTB- 2-nitro5-thiobenzoic acid; $\mathrm{O}_{2}$--superoxide; $\mathrm{OH}^{-}$-hydroxyl;
PR-pathogenesis related; PVP-polyvinyl pyrrolidone; ROS-reactive oxygen species; SA-salicylic acid; TBA- thiobarbituric acid; TCA-trichloroacetic acid.

\section{Introduction}

More than three quarters of the energy and half of the protein requirements of the current population are supplied by grains (Rajaram, 2001). In addition, in developing countries such as Iran,

\footnotetext{
1 Department of Agronomy and Plant Breeding, Faculty of Agriculture, University of Maragheh. Maragheh, Iran.

2 Associate Professor, Department of Agronomy and Plant Breeding, Faculty of Agriculture, University of Maragheh. Maragheh,Iran.

* Corresponding author: a.abbasi@ maragheh.ac.ir
} 
nearly half of daily energy consumption is directly obtained from wheat.

Water is one of the most important ecological factors determining wheat growth and development; any water deficit will cause serious damage to crop yield (Sankar, 2007). Drought stress occurs when the available water in the soil is reduced and atmospheric conditions cause continuous loss of water through transpiration or evaporation (Jaleel et al., 2008). Water deficit (commonly known as drought) can be defined as the absence of sufficient moisture for the plant to grow normally and complete its life cycle (Jaleel et al., 2008). Wheat yields are reduced by $50-90 \%$ of their irrigated potential in drought conditions in at least 60 million hectares in the developing world (Skovmand et al., 2001). Plants have to cope with drought stress at least at some point in their life cycle (Cruz de Carvalho, 2008). They have however evolved mechanisms that allow them to adapt and survive in the periods of water deficit (Noctor and Foyer, 1998). Plants are said to escape, avoid or tolerate drought stress according to the type of strategy adopted (Levitt, 1972). The plant's response to drought depends not only on the species' inherent "strategy" but also on the duration and severity of the drought period (Cruz de Carvalho, 2008). If prolonged over a certain extent, drought stress will inevitably result in oxidation (Smirnoff, 1993).

The alteration of antioxidant metabolisms is one of the fundamental metabolic processes that may influence drought tolerance (Da Costa and Huang, 2007). Drought stress promotes the production of reactive oxygen species (ROS), including superoxide $\left(\mathrm{O}^{2}-\right)$, singlet oxygen $\left({ }^{1} \mathrm{O}_{2}\right)$, hydroxyl $\left(\mathrm{OH}^{-}\right)$, and hydrogen peroxide $\left(\mathrm{H}_{2} \mathrm{O}_{2}\right)$, which can be detrimental to proteins, lipids, carbohydrates, and nucleic acids (Smirnoff, 1993). Under drought stress conditions, the reductive enzymatic pathways in plants may be overwhelmed and result in damage to cell components and finally death of the plant (Molassiotis et al., 2006). There are many studies that report on increased ROS accumulation and oxidative stress under drought stress (Boo and Jung, 1999). ROS are produced in normal and stressed cells (Alscher et al., 2002). Under stressful conditions ROS are biochemically accumulated in cells, however, they are kept under tight control by the antioxidant system. ROS are linked to phytohormones such as abscisic acid (ABA) and other ions and organic molecules. If cellular quantities of ROS are kept at relatively low levels they will act as a part of stress signaling pathway, but if they increase past a certain level they can damage the cell compartments phytotoxically (Cruz de Carvalho, 2008). ROS are produced from partial reduction of molecular oxygen (Unyayar and Ozlem, 2005). The first plant organ that detects a limitation in water supply is the root system. It has been shown that besides water and minerals, roots also send signals to the leaves through the xylem sap. The phytohormone abscisic acid is considered to be one of the major root-to-shoot stress signals in the leaves; it triggers stomata closure and the plant shifts to a water-saving strategy (Jiang et al., 2007). Hence, by adjusting stomatal opening plants are able to control water loss by reducing transpiration flux, but they concomitantly limit the entrance of carbon dioxide $\left(\mathrm{CO}_{2}\right)$. This will have direct and indirect effects on the reduction of net photosynthesis and on the overall production of ROS by plants under drought stress. In fact, under drought stress ROS production is enhanced through multiple ways (Mittler, 2002). For instance, the limitation on $\mathrm{CO}_{2}$ fixation will reduce $\mathrm{NADP}^{+}$regeneration through the Calvin cycle, and hence will provoke an overall reduction of the photosynthetic electron transport chain (Cruz de Carvalho, 2008).

It is well known that stress factors cause a shift in the prooxidant-antioxidant balance in plant cells. Plants have evolved several mechanisms to prevent or alleviate damage from ROS. These mechanisms include scavenging the ROS by natural antioxidants such as ascorbate and a-tocopherol and the use of an enzymatic antioxidant system that includes SOD, CAT, POX, APX, and GR, many of which act in tandem (Allen, 1995). Biotic and abiotic stresses adversely affect growth, metabolism and plant yields (Yildiz et al., 2007), and prevent them from expressing their full genetic potential (Zhu, 2002). In arid and semiarid regions, plants undergo oxidative stress that is a secondary drought stress. Plants protect themselves through increasing the scavenging capacity of ROS via antioxidant enzymes and molecules (Yildiz et al., 2007). Modulation of the activity of these enzymes may be an important factor in the tolerance of various plants to environmental stress (Rensburg and Kruger, 1994).

Salicylic acid (SA) is a phenolic compound synthesized throughout the plant kingdom via the phenylpropanoid pathway (Metraux, 2002). Research efforts over the past decade have focused on this molecule to elucidate its many roles in plant 
physiology. Detailed evidence implicates SA in pathogenesis-related gene expression, systemic acquired resistance and the hypersensitive response (Shah, 2003). SA also seems to be involved in responses to abiotic stresses (Nemeth et al., 2002), (Yang et al., 2004). However, the effects of salicylic acid on plant resistance to abiotic stress are usually contradictory. The same pre-treatment with exogenous SA results in opposite responses in different plant species (Yang et al., 2004). Even the same SA concentration promotes the resistance to one kind of stress while it decreases the resistance to another stress (Nemeth et al., 2002). The fact that SA can exert different effects under various stress situations or on different species is not a contradiction but rather illustrates the fact that different stresses can either be dependent on or independent of the SA pathway and the molecule does not have the same effect on all species. Because of this it is very important to study the timing and amount of salicylic acid treatment in plants. Pretreatment with exogenous SA (diluted in water and sprayed) increases tolerance to stresses (Ding et al., 2002). Some stress-protective proteins such as catalase (Ding et al., 2002) and HSP (Clarke et al., 2004) could be induced by SA treatment.

PBZ (2RS, 3RS)-1-(4-chlorophenyl)-4,4dimethyl-2- (1H-1,2,4-trizol-1-yl)-pentan-3-ol] is a triazolic group of fungicides which have PGR properties. The growth regulating properties of PBZ are mediated by changes in the balance of important plant hormones including the gibberellins, ABA and cytokinins (Berova et al., 2002). The application of PBZ has no harmful effects to human health and it has produced increased yield of crops. PBZ has been proven as an agent in stress amelioration in medicinal plants (Ucan et al., 2007). Paclobutrazol has been found to protect several crops from various environmental stresses including drought, chilling, heat and UV-B radiation (280-320 nm), although paclobutrazol-induced stress tolerance is reported to be due to increased antioxidant enzymes. The protection of plants from apparently unrelated stresses by triazole is also mediated by a reduction in free radical damage and increase in the antioxidant potential, and an efficient free-radical scavenging system that enables them to detoxify active oxygen (Kopyra, 2003).

The purpose of the present study was to determine whether paclobutrazol and salicylic acid could protect wheat seedling from injuries caused by drought stress.

\section{Materials and Methods}

Seeds of the wheat variety Bahar (obtained from Pakanbazr Seed Corporation in Esfahan, Iran) were used in the present study. They were surface sterilized with $10 \% \mathrm{H}_{2} \mathrm{O}_{2}$ for $20 \mathrm{~min}$, then washed several times with deionized water. The sterilized seeds were germinated in $25^{\circ} \mathrm{C}$ and dark conditions on filter paper for two days. Seedlings were initially hydro-cultured in aerated water and were grown in a growth chamber under 16:8 hours of light:dark, 25 ${ }^{\circ} \mathrm{C}, 65 \%$ relative humidity and light intensity of 6000 Lux. The sources of light inside the growth chamber were a combination of yellow and white florescent lamps. Seven and fourteen days after germination of the seeds, the tap water was replaced by half and full-strength Hoagland's nutrient solution, (Hoagland and Arnon, 1950). The amounts of each nutrient in solution in mmol were: 1 calcium nitrate $\left[\mathrm{Ca}\left(\mathrm{NO}_{3}\right)_{2}\right]$ $\left.4 \mathrm{H}_{2} \mathrm{O}\right] ; 0.1$ mono-potassium phosphate $\left(\mathrm{KH}_{2} \mathrm{PO}_{4}\right)$; 0.5 potassium sulfate $\left(\mathrm{K}_{2} \mathrm{SO}_{4}\right) ; 0.5$ magnesium sulfate $\left(\mathrm{MgSO}_{4}\right)$ and in $\mu \mathrm{mol}$ for boric acid, 10 $\left(\mathrm{H}_{3} \mathrm{BO}_{3}\right)$; manganese chloride, $20\left(\mathrm{MnCl}_{2} 4 \mathrm{H}_{2} \mathrm{O}\right)$; zinc sulfate, $0.5\left(\mathrm{ZnSO}_{4} 7 \mathrm{H}_{2} \mathrm{O}\right)$; copper sulfate, 1 $\left(\mathrm{CuSO}_{4} 5 \mathrm{H}_{2} \mathrm{O}\right)$; molybdenum trioxide, $0.1\left(\mathrm{MoO}_{3}\right)$, and iron sulfate, $100\left(\mathrm{FeSO}_{4} 7 \mathrm{H}_{2} \mathrm{O}\right)$. These solutions were continuously aerated by electrical pumps and renewed every three days.

The $\mathrm{pH}$ of the nutrient solution was measured with a $\mathrm{pH}$ meter and adjusted to 5.5 by adding 1 $\mathrm{N}$ sulfuric acid $\left(\mathrm{H}_{2} \mathrm{SO}_{4}\right)$. Once the seedlings grew to the 4 to 5-leaf stage, drought stress was applied using PEG-6000 (-6 and -12 bar potential). Plants were kept under stress conditions for 10 days.

In the preliminary experiments, 2, 5, 10, 15 and $20 \mathrm{mg} \mathrm{L}-1$ paclobutrazol and $0.05, .01, .0 .15$ and $0.2 \mathrm{~mm}$ salicylic acid were used for the treatment to determine the optimum concentration. Among the treatments, $5 \mathrm{mg} \mathrm{L}-1$ paclobutrazol and $0.1 \mathrm{~mm}$ salicylic acid increased the growth and dry weight significantly. The pretreatment selection was carried out simultaneously with drought stress. After 10 days full expanded leaf samples were transferred to liquid nitrogen and maintained at $-20{ }^{\circ} \mathrm{C}$ until measurement of biochemical parameters.

\section{Antioxidant enzyme assay}

The petal samples were frozen in liquid nitrogen and stored at $-30{ }^{\circ} \mathrm{C}$. One $\mathrm{g}$ of frozen petals was homogenized in a mortar with $5 \mathrm{ml}$ of $50 \mathrm{mM}$ 
potassium phosphate buffer ( $\mathrm{pH} 7.5$ ) containing 1 mM EDTA, $1 \mathrm{mM}$ dithiotreitol and $2 \%$ polyvinyl pyrrolidone (PVP). The homogenate was centrifuged at $15,000 \mathrm{~g}$ for $25 \mathrm{~min}$ and the supernatant was used for SOD and CAT assay.

\section{Superoxide dismutase assay}

The activity of SOD (EC 1.15.1.1) was determined according to Beyer and Fridowich (1987). In small glass tubes, $20 \mu \mathrm{L}$ of enzyme supernatant was added to $50 \mathrm{mM}$ potassium phosphate buffer (pH 7.8), $9.9 \mathrm{mM}$ L-methionine, $57 \mu \mathrm{M}$ nitro blue tetrazolium (NBT), and $0.025 \%$ triton-X-100. The reaction was started under fluorescent light for 10 minutes by adding $10 \mu \mathrm{L}$ of riboflavin solution. Absorbance of the solution was measured at 560 $\mathrm{nm}$ for both blank and control. SOD activity was expressed as Unit $\mathrm{mg}^{-1} \mathrm{DW}$.

\section{Catalase assay}

The activity of CAT (EC 1.11.1.6) was assayed according to Chance and Maehly (1955). A $1.5 \mathrm{~mL}$ reaction mixture containing $30 \mu \mathrm{L}$ water, $50 \mu \mathrm{L} 1 \mathrm{M}$ Tris-HCl buffer ( $\mathrm{pH}$ 8.0), 5 mM EDTA and 900 $\mu \mathrm{L} 10 \mathrm{mM} \mathrm{H} \mathrm{O}_{2}$ was added to $20 \mu \mathrm{L}$ of enzyme supernatant. The decrease in the absorbance at 240 $\mathrm{nm}$ was recorded for 60 seconds. CAT activity was expressed as absorbance in $\mathrm{mg}$ protein per min.

\section{Ascorbate peroxidase enzyme assay}

Ro measures ascorbate peroxidase enzyme activity; $0.1 \mathrm{ml}$ of enzyme extract was dissolved in the reactive solution including $100 \mathrm{mmol}$ potassium phosphate buffer ( $\mathrm{pH} 7), 0.22 \mathrm{mmol}$ ascorbate and $0.3 \mathrm{mmol}_{2} \mathrm{O}_{2} 3 \%$. The ascorbate was then spectrophotometrically recorded at $290 \mathrm{~nm}$. In order to protect enzyme activity, the first stages were done in ice dishes.

\section{Lipid peroxidation assay}

Lipid peroxidation was measured in terms of the malondialdehyde (MDA) content of petals as described by Stewart and Bewley (1980), using a colorimetric method. Petal samples were homogenized in $2 \mathrm{ml} 0.1 \%$ trichloroacetic acid (TCA) and centrifuged. Then $0.5 \mathrm{ml}$ of supernatant was mixed with $2 \mathrm{ml}$ of $20 \%$ TCA containing $0.5 \%$ thiobarbituric acid. The mixture was incubated at $95^{\circ} \mathrm{C}$ for 30 minutes. The samples were centrifuged at $10,000 \mathrm{~g}$ for 10 minutes. The absorbance of the supernatant was read at 532 and $600 \mathrm{~nm}$. The amount of MDA was calculated from the extinction coefficient of $155 \mathrm{mM}^{-1} \mathrm{~cm}^{-1}$.

\section{Chlorophyll content}

Chlorophyll content was extracted from Patumma leaves with dimethyl sulfoside (DMSO) and spectrophotometrically determined according to the modified method of Chappelle et al. (1992).

\section{Determination of $\mathrm{H}_{2} \mathrm{O}_{2}$ content}

Hydrogen peroxide levels were determined according to Sergive et al., (1997). Leaf tissues $(0.5 \mathrm{~g})$ were homogenized in an ice bath with $5 \mathrm{ml}$ $0.1 \%(\mathrm{w} / \mathrm{v})$ TCA. The homogenate was centrifuged at $12000 \times \mathrm{g}$ for $15 \mathrm{~min}$ and $0.5 \mathrm{ml}$ of the supernatant was added to $0.5 \mathrm{ml} 10 \mathrm{mM}$ potassium phosphate buffer $(\mathrm{pH}=7.0)$ and $1 \mathrm{ml} 1 \mathrm{M} \mathrm{KI}$. The absorbance level of supernatant was read at $390 \mathrm{~nm}$. The content of $\mathrm{H}_{2} \mathrm{O}_{2}$ was interpolated from a standard curve.

Protein content of samples was determined by the method of Bradford (1976); bovine serum albumin was used as a standard.

All physiological and biochemical parameters were measured with four replications. The data were analyzed with SPSS software. Comparison of means was performed with MSTATC and carried out by the LSD method.

\section{Results and Discussion}

The effects of PBZ and SA treatments on wheat were monitored by measuring changes in CAT, APX, SOD, GPX, MDA, $\mathrm{H}_{2} \mathrm{O}_{2}$ and chlorophyll under drought stress. Both PBZ and SA increased the antioxidant enzyme activity and displayed a significant difference $(\mathrm{p}<0.001$ and 0.05 , respectively).

The effects of hormone treatments are shown in the figures. The interaction of drought and hormones on APX activity was significant. APX activity decreased under drought condition, but treatments resulted in increased APX activity in the drought stress treatments. PBZ in combination with drought also caused enhancement in APX activity compared to six control plants, nearly $33.33 \%$ and $133 \%$ over 
the control on day 3 with -6 and -12 Bar. However, these amounts decreased in the following days. SA increased APX activity significantly in both drought conditions compared to other treatments, but this gain was less than with PBZ. Kraus and Fletcher (1994) proposed that PBZ-induced protection of wheat from damage caused by heat stress was mediated by increased SOD, APX and GPX activity. Jaleel (2008) showed that APX activity increased under salt stress with paclobutrazol treatment. In our study, PBZ treatment appears to be an important strategy for altering the behavior and survival of wheat under drought stress. PBZ apparently plays an important role in the antioxidative system under stress (Lin et al., 2008). Drought stress protection conferred by PBZ was mediated to some extent by an enhanced antioxidative system. In addition, Jaleel (2008) reported exogenous application of PBZ affects the antioxidant defense system by modifying enzyme activity.

Figure 4 shows that SOD activity without hormone treatment under drought stress declined; maximum SOD activity occurred without stress. The trend of change in SOD activity of untreated plants under drought stress was a decline to 0.06 units $/ \mathrm{mg}$ protein over time, but decreased less with hormone treatment. Plants are natural producers of RPS and SOD that are the front line enzymes in ROS attack, since they rapidly scavenge the superoxide and dismutase to oxygen and $\mathrm{H}_{2} \mathrm{O}_{2}$. The enzyme $\mathrm{SOD}$ dismutates $\mathrm{O}_{2}{ }^{-}$to $\mathrm{H}_{2} \mathrm{O}_{2}$ and is present in the cytosol and different cell organelles. SODs are classified based on the metal present in the catalytic site, i.e. $\mathrm{Cu} / \mathrm{Zn}-\mathrm{SOD}$ localized in cytosol and chloroplast, Fe-SOD in chloroplasts and Mn-SOD in the mitochondrial matrix and peroxisomes (Ushimaru et al., 1995). There are a considerable number of reports in the literature on the fluctuations (Pinhero, 1997). SOD activity was greatly increased in PBZtreated wheat, which was 90 percent above the control on day 3 . The SA also caused an increase in this enzyme activity. It was 70 percent over the control on day 3. Manivannan (2008) reported an increase in SOD activity in Helianthus annuus plants under water deficit stress and triazol application; it is conceivable that SA-induced activation of SOD is

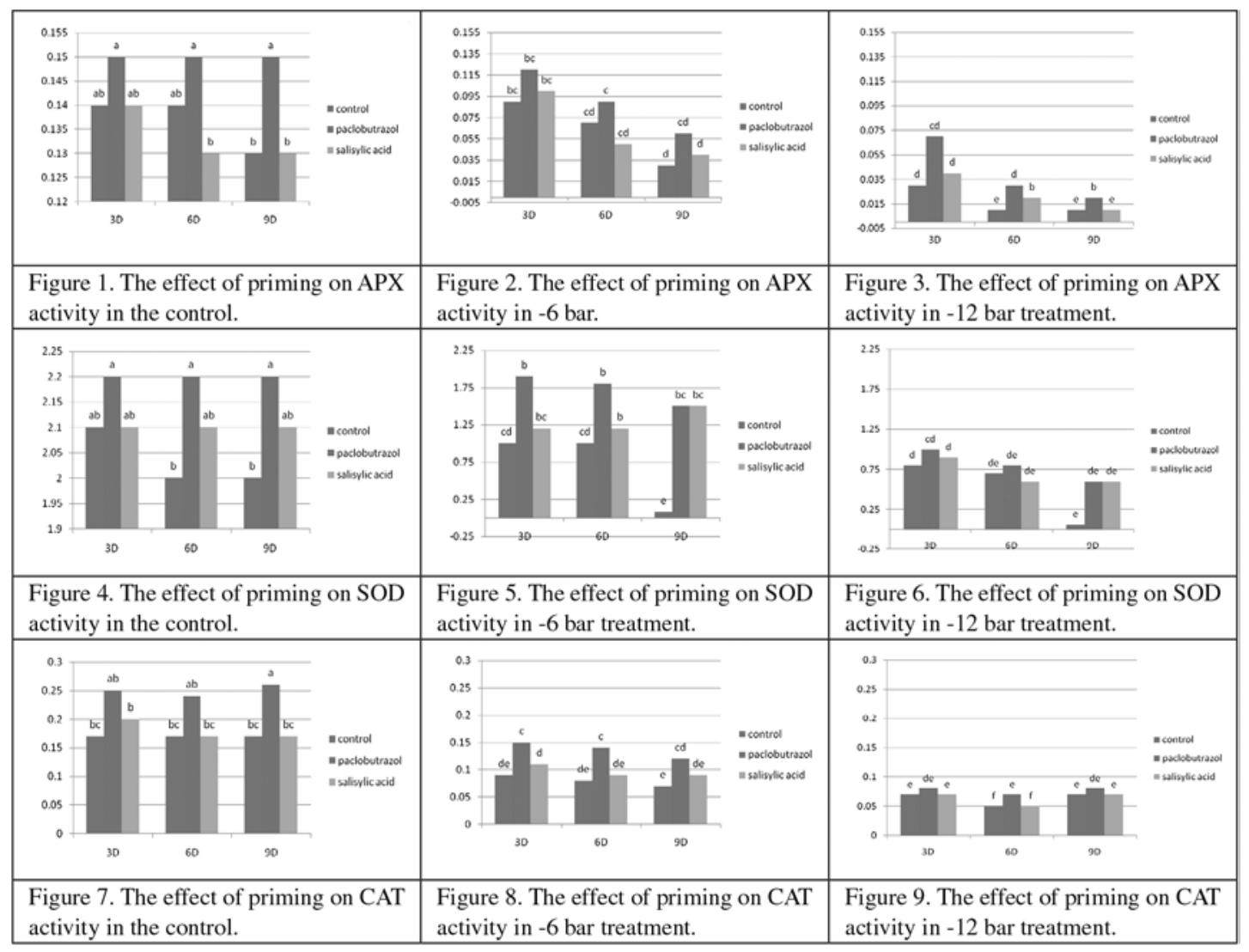




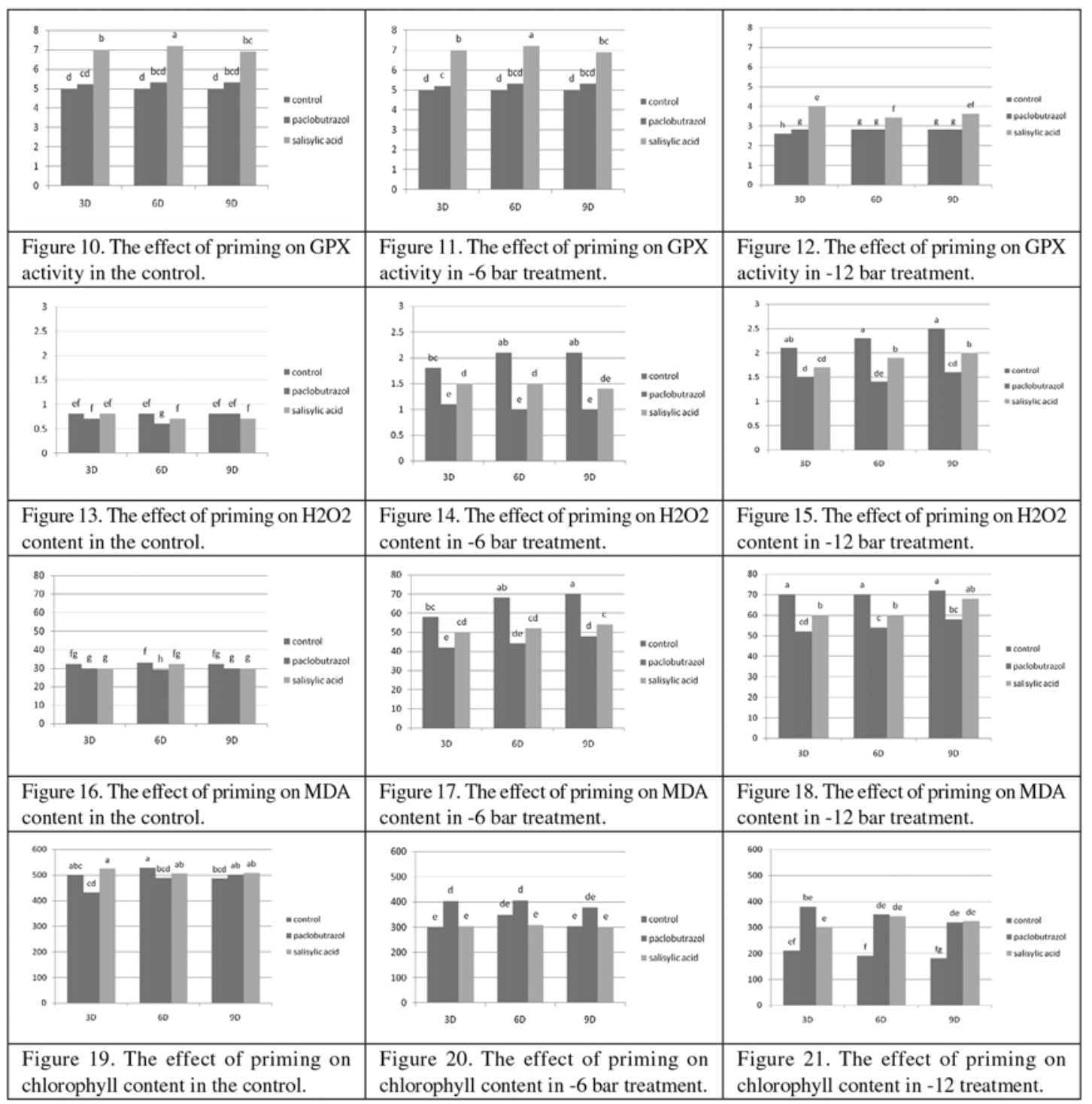

due to its effect on ABA, because it is well known that $\mathrm{ABA}$ is involved in the process of induction of the expression of genes encoding proteins involved in plant stress responses, including the genes of SOD (Jaleel et al., 2008).

CAT enzyme is an important antioxidant system that catabolizes hydrogen peroxide, a precursor of reactive oxidants (Larson et al., 1988) and directly reacts with $\mathrm{H}_{2} \mathrm{O}_{2}$ to form water and oxygen (Winston et al., 1990). The CAT activity followed a trend similar to SOD. This enzyme activity was significantly higher in the control. The enzyme activity was reduced with stress, but increased in PBZ treatment to $66.66 \%$ over the control on day 3 .
Similar effects of PBZ on increasing the antioxidant CAT activity have also been observed by other studies (Sankar et al., 2007; Somasundaram et al., 2009). Jaleel et al. (2008) also reported that PBZ-treated plants have a very efficient antioxidative defense mechanism for detoxifying and scavenging of toxic oxygen species through an adoptive mechanism involving upregulation of antioxidative enzymes such as CAT. Therefore, the results in wheat are consistent with the findings by Fletcher (2000), who suggested that triazole compounds induce stress tolerance in plants due to increased antioxidant activity. The $\mathrm{H}_{2} \mathrm{O}_{2}$ scavenging system represented by CAT is more important in imparting tolerance 
than SOD, as reported for oxidative stress in wheat (Sairam et al., 1998).

GPX activity did not change significantly with PBZ treatment compared to the control, but the SA-supplemented seedlings under drought stress caused a profound increase in GPX activity $(100 \%$ and 53\% higher at -6 and -12 bar PEG on day 3) compared to stressed seedlings without SA spray. Glutathione peroxidases (GPXs) are a large family of diverse isozymes that use GSH to reduce $\mathrm{H}_{2} \mathrm{O}_{2}$ and lipid hydroperoxides (LOOHs), and therefore protect plant cells from oxidative stress (Noctor $\mathrm{et} \mathrm{al}$. 2002). GPX is also a main cellular enzyme capable of repairing membrane lipid peroxidation and is an important protectant against oxidative membrane damage (Kühn and Borchert 2002). In line with this result, Kadioglu et al. 2011 showed that exogenous SA enhances the activity of this enzyme, which helps to detoxify $\mathrm{H}_{2} \mathrm{O}_{2}$ and prevent lipid peroxidation.

In our study, drought stress caused a remarkable increase in lipid peroxidation (MDA content), while exogenous SA and PBZ treatments prevented lipid peroxidation at any level of stress (Fig. 16, 17, 18). This was due to the prevention of membrane damage and induction of antioxidant responses by PBZ and $\mathrm{SA}$, which protects the plant from oxidative damage. A similar protective effect of SA and PBZ treatment was also observed by Senaratna et al. (2000) and Kadioglu et al. (2011). MDA is one final decomposition product of lipid peroxidation and has been used as an index for the status of lipid peroxidation. At higher concentration $\mathrm{H}_{2} \mathrm{O}_{2}$ leads to oxidative stress (Quan et al. 2008), and it may inactivate enzymes by oxidizing their thiol groups. In our study, drought stress caused a remarkable increase of $\mathrm{H}_{2} \mathrm{O}_{2}$ content, which is a clear indication of oxidative stress and increased MDA. Spraying with PBZ and SA, on the other hand, prevented the accumulation of $\mathrm{H}_{2} \mathrm{O}_{2}$ in drought stressed plants, due to the upregulation of $\mathrm{H}_{2} \mathrm{O}_{2}$ scavenging enzymes such as GPX, APX and CAT (Fig. 1-3 and Fig 7-12). This result is in good agreement with Kadioglu et al. (2011) and Alam (2013). In our experiment the MDA content in the paclobutrazol and salicylic acid-treated plants was lower than the control (Fig. 13, 14 and 15). The reduction of lipid peroxidation in the paclobutrazol treatment was caused by paclobutrazol increasing the antioxidant potential system. As in other studies, stresses can be minimized by the application of paclobutrazol by increasing the antioxidant levels and activities of scavenging enzymes such as GPX, SOD, APX, and CAT (Sankar et al., 2007).

Drought stress reduced total chlorophyll content (Fig. 19). Paclobutrazol had higher total chlorophyll content in -6 and -12 bar (Fig. 20 and 21). Total chlorophyll content was higher in PBZ treatment compared to SA treatment. Paclobutrazol alone and in combination with drought increased the total chlorophyll (Abraham et al., 2008). Sebastian et al. (2002) reported enhanced chlorophyll synthesis in Dianthus treated with paclobutrazol. The higher chlorophyll content in triazole-treated radish may be related to the influence of triazole on endogenous cytokinin levels. It has been proposed that triazoles stimulate cytokinin synthesis that enhances chloroplast differentiation, chlorophyll biosynthesis and prevents chlorophyll degradation (Fletcher et al., 2000).

Our results showed that paclobutrazol minimizes the negative effects of drought stress, with evidence of enhancing chlorophyll content and antioxidant enzymes such as APX, CAT and GPX that reduce $\mathrm{H}_{2} \mathrm{O}_{2}$ and lipid peroxidation (MDA) content.

\section{Literature Cited}

Abraham. S.S.; Jaleel, C.A.; Chang-Xing Z.; Somasundaram, R.; Azooz, M.M.; Manivannan, P.; Panneerselvam, R. 2008. Regulation of Growth and Metabolism by Paclobutrazol and ABA in Sesamum indi cum L. Under Drought Condition. J. Molec. Sci., 3 (2): 57-66.

Alam, M.M.; Hasanuzzaman, M.; Nahar, K.; Fujita, M.

2013. Exogenous salicylic acid ameliorates short-term drought stress in mustard (Brassica juncea L.) seedlings by up-regulating the antioxidant defense and glyoxalase system. AJCS, 7(7): 1053-1063.

Allen, R.D.

1995. Dissection of oxidative stress tolerance using transgenic plants. Plant Physiol, 107: 1049-1054.
Alscher, R.G.; Erturk, N.; Heath, L.S.

2002. Role of superoxide dismutases (SODs) in controlling oxidative strese in plants. J. Exp. Bot., 53:1331-1341.

Berova, M.; Zlatev, Z.; Stoeva, N.

2002. Effect of paclobutrazol on wheat seedlings under low temperaturestress. Bulg. J. Plant Physiol., 28: 75-84.

Boo, Y.C.; Jung, J. 1999. Water deficit-induced oxidative stress and antioxidative defenses in rice plants. J Plant Physiol, 155:255-261.

Bradford, M. M.

1976. A rapid and sensitive method for the quantitation of microgram quantities of protein utilizing the principle of protein-dye binding. Analytical Biochemistry, 72:248-254. 
Chappelle, E. W.; Kim, M. S.; McMurtrey, J. E.

1992. Ratio analysis of reflectance spectra (RARS): An algorithm for remote estimation of the concentrations of chlorophyll a, chlorophyll b, and carotenoids. Remote Sens. Environ., 39:239-247.

Clarke, S. M.; Mur, L.A.J.; Wood, J. E.; Scott, I.M.

2004. Salicylic acid dependent signaling promotes basal thermotolerance but is not essential for acquired thermotolerance in Arabidopsis thaliana. Plant J., 38, 432-447.

Cruz de Carvalho, M. H..

2008. Drought stress and reactive oxygen species. Plant Signaling \& Behavior, 3(3): 156-165.

Da Costa, M.; Huang, B.

2007. Changes in antioxidant enzyme activities and lipid peroxidation for bent grass species in responses to drought stress. J. Am. Soc. Hortic. Sci., 132:319-326.

Ding, C.K.; Wang, C.Y.; Gross, K.C.; Smith, D.L.

2002. Jasmonate and salicylate induce the expres- sion of pathogenesis-related-protein genes and in- crease resistance to chilling injury in tomato fruit. Planta, 214:895-901.

Fletcher, R.A.; Angella, G.; Sankala, N.; Tim, D.

2000. Triazoles as plant growth regulators and stress protectors. Hort. Rev. 24:55-105. Hedden P, and Kamiya Y (1997). Gibberellin biosynthesis:enzymes, genes and their regulation. Ann. Rev. Plant Physiol. Plant Molec. Biol., 48: 431-460.

Hoagland, D.R.; Arnon, D.I.

1950. The water culture method for growing plants without soil. California Agricultural Experiment Station Circular, No. 347. Berkely, CA: University of California. 34p.

Jaleel, C.A.; Azooz, M.M.; Manivannan, P. Panneerselvam, R. 2008. Involvement of paclobutrazol and ABA on droughtinduced osmoregulation in Cajanus cajan. American-Eurasian J. Bot., 1(2): 46-52.

Jaleel, C.A.; Gopi, R.; Sankar, B.; Gomathinayagam, M.; Panneerselvam, R.

2008. Differential responses in water use efficiency in two varieties of Catharanthus roseus under drought stress. Comptes Rendus Biologies, 331(1): 42-47.

Jaleel, C.A.; Manivannan, P.; Lakshmanan, G.M.A.;

Gomathinayagam, M.; Panneerselvam, R.

2008. Alterations in morphological parameters and photosynthetic pigment responses of Catharanthus roseus under soil water deficits. Colloids and Surfaces B: Biointerfaces, 61(2): 298-303

Jiang, F.; Hartung, W.

2008. Long-distance signalling of abscisic acid (ABA): The factors regulating the intensity of the ABA signal. J. Exp. Bot., 59(1):37-43.

Kadioglu, A.; Saruhan, N.; Sağlam, A.; Terzi, R.; Acet, T.

2011. Exogenous salicylic acid alleviates effects of long term drought stress and delays leaf rolling by inducing antioxidant system. Plant Growth Regul, 64:27-37.

Kopyra, M.; Gwozdz, E.A.

2003. Antioxidant enzymes in paraquat and cadmium resistant cell lines of horseradish. Biol. Lett., 40: 61-69.

Kraus, T.E; Fletcher, R.A.

1994. Paclobutrazol protects wheat seedlings from heat and paraquat injury. Is detoxification of active oxygen involved? Plant Cell Physiol., 35: 45-52.
Kühn, H.; Borchert, A.

2002. Regulation of enzymatic lipid peroxidation: the interplay of peroxidizing and peroxide reducing enzymes. Free Rad. Biol. Med., 33:154-172.

Larson, M.H.; Davis, T.D.; Evans, R.P.

1988. Modulation of protein expression in uniconazole treated soybean in relation to heat stress, Proc. Plant Growth Reg. Soc. Am ., $15: 177-182$.

Levitt, J.

1972. Responses of plants to environmental stresses. New York: Academic Press.698 p.

Lin, H.K.; Tsou, C.C.; Hwang, S.Y.; Chen, L.F.O.; Lo, H.F. 2008. Paclobutrazol leads to enhanced antioxidative protection of sweetpotato under flooding stress. Botanical Studies, 49: 9-18.

Manivannan, P., C. Abdul Jaleel, R. Somasundaram and R.

Panneerselvam.

2008. Osmoregulation and antioxidant metabolism in drought stressed Helianthus annuus under triadimefon drenching. Comptes Rendus Biologies, 331(6): 418-425.

Metraux J. P.

2002. Recent breakthroughs in the study of salicylic acid biosynthesis. Trends Plant Sci., 7: 332-334.

Mittler R.

2002. Oxidative stress, antioxidants and stress tolerance. Trends Plant Sci., 7:405-410.

Molassiotis, A.; Sotiropoulos, T.; Tanou, G.; Diamantidis, G.; Therios, I.

2006. Boron-induced oxidative damage, antioxidant and nucleolytic responses in shoot tip culture of the apple rootstock EM9 ( Malus domestica Borkh). Environ. Exp. Bot ., 56: 54-62.

Nemeth, M.; Janda, T.; Horvath, E.; Paldi, E.; Szalai, G.

2002. Exogenous salicylic acid increases polyamine content but may decrease drought tolerance in maize. Plant Sci., 162: 569-574.

Noctor, G.; Foyer, C.H.

1998. Ascorbate and glutathione: Keeping active oxygen under control. Annu. Rev. Plant Physiol. Plant Mol. Biol.; 49:249-279.

Pinhero. R.G.; Rao, M.V.; Paliyath, C.; Murr, D.P.; Fletcher, R.A. 1997. Changes in Activities of Antioxidant Enzymes and Their Relationship to Genetic and Paclobutrazol-Induced Chilling Tolerance of Maize Seedlings. Plant Physiol., 11 4:695-704

Quan, L.J.; Zhang, B.; Shi, W.; Li, H.Y.

2008. Hydrogen peroxide in plants: a versatile molecule of the reactive oxygen species network. J. Integr. Plant Biol., 50: $2-18$.

Rajaram, S.

2001. Prospects and Promise of Wheat breeding in the $21 \mathrm{st}$ century. Euphtica, 119:3-15.

Rensburg, L.V.; Kruger, G.H.J.

1994. Evaluation of components of oxidative stress metabolism for use in selection of drought tolerant cultivars of Nicotiana tabacum L. Journal of Plant Physiology, 143: 730-737.

Sairam, R.K.; Deshmukh, P.S.; Saxena, D.C.

1998. Role of antioxidant systems in wheat genotypes tolerance to water stress. Biol. Plant., 41: 387-394. 
Sankar, B.; Jaleel, C.A.; Manivannan, P.; Kishorekumar, A.; Somasundaram, R.; Panneerselvam, R.

2007. Effect of paclobutrazol on water stress amelioration through antioxidants and free radical scavenging enzymes in Arachis hypogaea L. Colloids and Surf. B: Biointerfaces, 60: 229-235.

Sebastian, B.; Alberto, G.; Emilio, A.C.; Jose, A.F.; Juan, A.F. 2002. Growth development and color response of potted Dianthus caryophyllus to paclobutrazol treatment. Sci. Hort. 1767: 1-7.

Senaratna, T.; Touvhell, D.; Bunn, E.; Dixon, K. 2000. Acetyl salicylic acid (aspirin) and salicylic acid induce multiple stress tolerance in bean and tomato plant. Plant Growth Regul., 30: 157-161.

Shah, J.

2003. The salicylic acid loop in plant defense. Curr. Opin. Plant Biol., 6: 365-371.

Skovmand, B.; Reynolds, M.P.; Delacy, I.H.

2001. Searching genetic resources for physiological traits with potential for increasing yield. In: Reynolds M P, OrtizMonasterio J I \& McNab A, eds. Applications of physiology in wheat breeding. DF: CIMMYT, Mexico. 17-28 pp.

Smirnoff, N.

1993. The role of active oxygen in the response of plants to water deficit and desic-cation. New Phytol., 125: 27-58.

Somasundaram, R.; Jaleel, C.A.; Abraham, S.S.; Azooz, M.M.; Panneerselvam, R.

2009. Role of paclobutrazol and ABA in drought stress amelioration in Sesamum indicum L. Global J. of Molecular Sci., 4(2): 56-62.
Ucan, K.; Killi, F.; Gencoglan, C.; Merdun, H.

2007. Effect of irrigation frequency and amount on water use efficiency andyield of sesame (Sesamum indicum L.) under field conditions. Field Crops Res., 101: 249-258.

Unyayar, S.; Ozlem Cekic, F.

2005. Changes in Antioxidative Enzymes of Young and Mature Leaves of Tomato Seedlings under Drought Stress. Turk J. Biol ., 29: 211-216.

Ushimaru, T.; Ogawa, K.; Ishida, N.; Shibasaka, M.; Kanematsu, S.; Asada, K.; Tsuji, H.

1995. Changes in organelle superoxide dis- mutase isozymes during air adaptation of submerged rice seedlings: differential behaviour of isozymes in plastids and mitochondria. Planta, 112: 606-613.

Winston, G.W.

1990. Physiochemical Basis for Free Radical Formation in Cells, Production and Defenses. In: Alscher R.G. and Cumming J.R. (Eds.), Stress Responses in Plants, Adaptation and Acclimation Mechanisms. Wiley Liss, New York, 57-86 pp.

Yang, Y. N.; Qi, M.; Mei, C. S.

2004. Endogenous salicylic acid protects rice plants from oxidative dam-age caused by aging as well as biotic and abiotic stress. Plant J. 40: 909-919.

Yildiz Aktas, L.; Turkyilmaz, B.; Akca, H.; Parlak, S. 2007. Role of Abscisic Acid and Proline Treatment on Induction of Antioxidant Enzyme Activities and Drought Tolerance Responses of Laurus nobilis L. Seedlings. Fen. Bilimleri Dergisi, 28: 14-27. 
